\title{
Рецензия на книгу: \\ В.К. МерЦ «КРАТКАЯ ИСТОРИЯ РАЗВИТИЯ МАТЕРИАЛЬНОЙ КУЛЬТУРЫ ПАВЛОДАРСКОГО ПРИИРТЫШЬЯ». \\ Павлодар: Павлодарский государственный университет им. С. Торайгырова, 2019. 142 c.
}

\section{(C) 2019 г. А.М. Досымбаева}

Монография состоит из Введения, 11 глав, соответствующих хронологической периодизации исследованных и представленных в содержании памятников, расположенных на территории региона, списка литературы. В научном труде подведены итоги 30-летних научных исследований и анализа материалов, ранее опубликованных в более чем в 200 статьях в республиканских и зарубежных изданиях. Основные результаты комплексного исследования археологических памятников базируются на открытиях автора монографии, опытного и профессионального ученого, Виктора Карловича Мерца, многие годы посвятившего изысканиям Павлодарского Прииртышья.

Широта научных познаний автора издания, позволившая выработать особый подход к исследованию целых групп памятников, нашла отражение в тексте издания, скрупулезно выполненных графических, фотографических и картографических иллюстрациях. Значительный интерес представляет умение распознавания ландшафтных особенностей залегания тех или иных памятников, документальное фотосопровождение, которое совместно с описанием предоставляет широкому кругу читателей возможность для ознакомления и понимания особенностей культурного развития населения в ту или иную эпоху. артефакт

Ключевые слова: археология, хронология, наследие, эпоха, каменный век,

Монография «Краткая история развития материальной культуры Павлодарского Прииртышья» представляет собой издание, в котором доступным языком изложены вопросы изучения, сохранения и популяризации культурного наследия описываемого региона. Особый интерес представляют главы книги, посвященные истории становления культуры человека в каменном веке - периоде освоения человеком каменной индустрии. По наблюдениям ученого «...наиболее древние стратифициро- ванные местонахождения эпохи раннего палеолита привязаны к нижнеантропогеновым отложениям речных и озерных террас на Правобережье Иртыша, у сел Акку (Лебяжье), Жамбыл, Жанааул, оз. Маралды и в г. Павлодар» [с. 10 - здесь и далее в квадратных скобках даны ссылки на рецензируемую работу]. Описываемая группа, представленная примитивной галечной индустрией совместно с неогеновой фауной, происходящей из древнейших отложений террас реки Иртыш, по мнению автора, воз- 


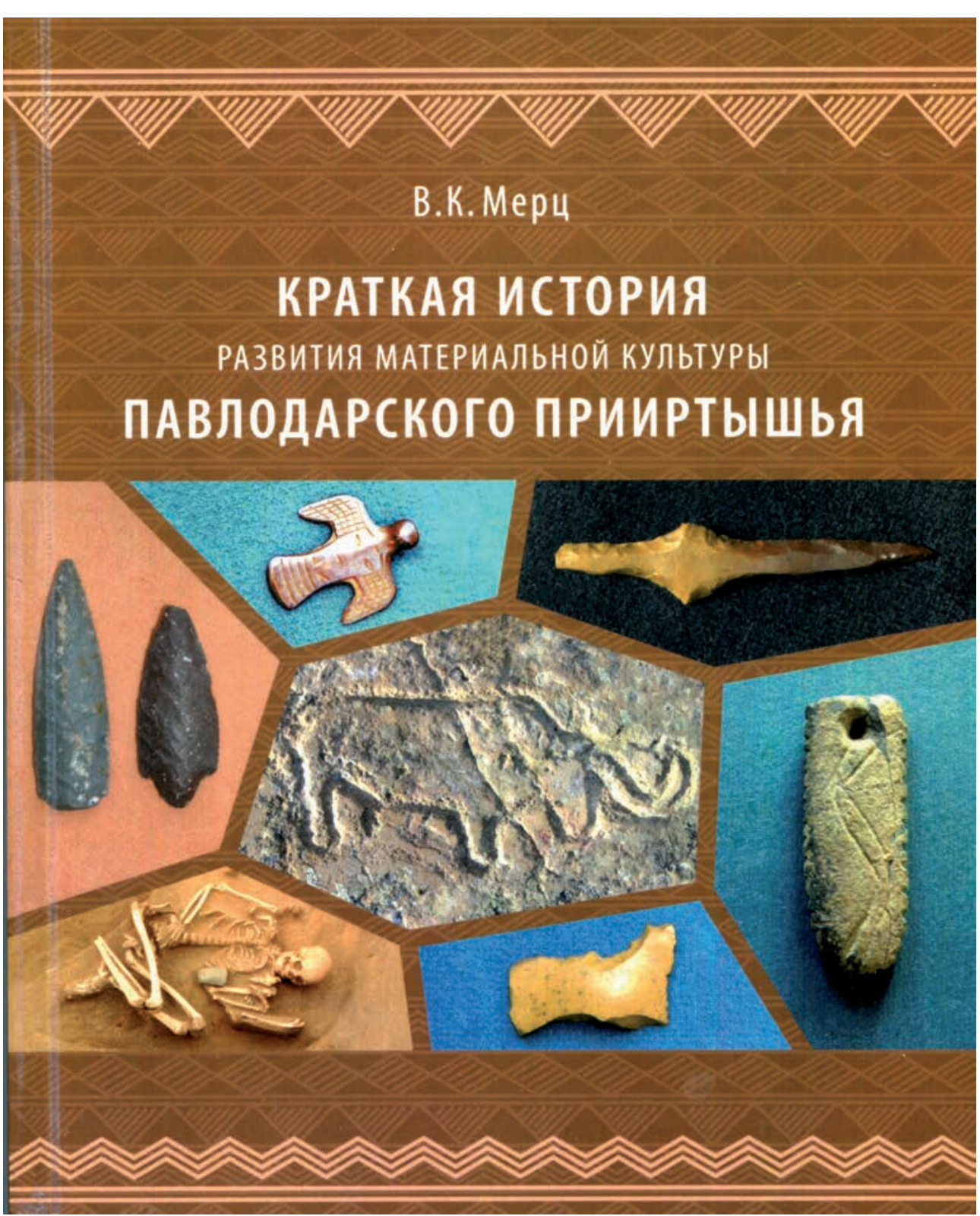

можно, является наиболее ранними памятниками эпохи палеолита на территории Казахстана и насчитывает возраст 1,5 млн. лет. В результате профессиональных изысканий в местах локализации каменных орудий, ученым были обнаружены кости животных (лошади, китайской газели, оленей, носорога), существование которых и деятельность человека, охотившегося на них, может свидетельствовать о раннем этапе антропогенеза на территории Павлодарского Прииртышья. Наряду с результатами изучения раннепалеолитических памятников в книге представлены и материалы эпох среднего и верхнего палеолита.

Последовательное развитие культуры населения, производства 
каменной индустрии в среднекаменном веке основано на изучении многослойных памятников, открытых автором на стоянках Шидерты 3, Ангренсор 2, Кудайколь 4, Карабудур 3 [c. 22] и ряде других местонахождений, где были собраны остатки каменных индустрий мезолитического облика.

Несмотря на слабую изученность эпохи мезолита в целом и особенностей развития технологических особенностей производства каменных орудий, автору удается выявить их изменения. Ученым произведен тщательный анализ артефактов из слоев 5 и 6 многослойного памятника Шидерты 3 и других стоянок c характерной микропластинчатой индустрией с коническими и призматическими нуклеусами, торцовидной и клиновидной формы небольших размеров, множеством сечений и целых микропластин без вторичной обработки. Исследователь обращает внимание на произошедшие в каменной индустрии мезолита изменения и, характеризуя артефакты, пишет, что: «В качестве орудий использовались в основном медиальные сечения микропластин $<\ldots>$. Имеются проколки, концевые скребки на пластинах шириною более 1 см <...> Особенностью комплекса являются резцы <..>.» [c. 23]. Безусловная связь развития особенностей культуры человека в эпоху мезолита с климатическими изменениями для автора очевидна. Описывая общую ситуацию развития культуры населения региона в среднем каменном веке, ученым отмечается ее взаимная связь со сходными памятниками Южного Урала, Западной Сибири и Средней Азии.

Наиболее разработанными, профессионально изученными и ши- роко представленными в монографии являются памятники следующей эпохи - неолита. Открытие и логически продуманный подход к исследованию многослойного памятника Шидерты 3 позволили ученому прийти к выводам о дробной периодизации эпохи в целом и выделить этапы развития в периоды раннего, среднего и позднего неолита. Основанием для выводов послужили использование комплексного метода в исследовании памятника: изучение артефактов, приведших к выделению различных типов каменной индустрии, отличающихся друг от друга и характерных для определенного периода развития, данные по стратиграфии залегания и результаты радиоуглеродного анализа.

Ранний период нового каменного века представлен материалами слоя 3 стоянки Шидерты 3, артефакты которого имеют свои типологические особенности, это «< .. > плоскостные, конические, призматические и реже клиновидные нуклеусы с фасетированными ударными площадками, служившими для получения тонких призматических пластин шириною в среднем до 1-1,2 см. На сечениях пластин длиною 1,5 - 3-4 см выполнена основная часть орудий. Среди них $-<\ldots>$ вкладыши $<\ldots>$; асимметричные высокие трапеции и симметричные низкие; асимметричный параллелограмм с притупленным краем; скошенные острия; проколки; развертки; острия с притупленной спинкой и торцом; пластинки с выделенной головкой; различные сечения с ретушированной боковой выемкой; ножи; боковые скребки с вентральной ретушью по одному или двум краям; крупные вкладыши с вентральной ретушью и притупленным торцом» [c. 46]. Результаты комплексного ис- 
следования позволили датировать ранний период развития описываемого памятника VI тыс. до н.э.

При выделении следующих этапов развития культуры населения эпохи неолита использованы те же методы комплексного анализа источников. Автором прослеживается технологическая революция в каменной индустрии. Особенности производства орудий прослежены по способам обработки и изготовления каменных орудий: огранке лезвий, ретушированию и способам использования различных каменных изделий в качестве ножей, вкладышей для костяных рукояток и др. Вместе с тем, в культурных слоях стоянок Шидерты 3, Кудайколь, Пеньки 1 отчетливо зафиксированы типы жилого пространства с очагами, найдены керамические изделия с характерными для позднего неолита формами и мотивами орнаментации [с. 61-63].

Среди открытых в Павлодарском Прииртышье памятников эпохи неолита представлены и захоронения, выполнен анализ комплекса инвентаря, включающий изделия из камня, костей, керамический материал и украшения. Это позволило атрибутировать захоронения из Железинского и Шидертинского погребений эпохами неолита и переходного периода к энеолиту и интерпретировать их как одни из древнейших свидетельств существования древней культуры на территории Казахстана [c. 65-71]. Непревзойденную ценность представляют результаты антропологической реконструкции, позволяющей ознакомиться с обликом человека, характерными особенностями которого являлись уже сформированная расовая принадлежность с признаками монголоидности [с. 69]. Заслуживают особого внимания и выводы ученого том, что: «Орудийный набор поздненеолитических и энеолитических стоянок и фаунистические остатки, найденные на них, свидетельствуют о хозяйственной направленности, связанной не только с охотой, но и скотоводством» [с. 71]. Так, по мнению автора, материалы, полученные на поселении Борлы, где обнаружено большое количество костей домашней лошади и КРС, свидетельствует в пользу предположения о существовании здесь древнейшего центра доместикации животных.

Энеолитический период развития культуры населения региона изучен по материалам ряда поселений, среди которых наиболее результативными оказались Шидерты 3 и Борлы 4. Изменения, произошедшие в экономическом развитии, более направленном на способы ведения производящего хозяйства, оказали свое влияние и на облик орудий труда, новые технологии в их изготовлении. По мнению автора монографии, «в эпоху энеолита в Павлодарском Прииртышье, как и во всех регионах Евразийской степи, складываются формы хозяйства, наиболее оптимальные и продуктивные для этой экосистемы, получившие дальнейшее развитие в последующие эпохи» [с. 83]. Энеолитические комплексы региона отражают те кардинальные изменения, которые произошли и в орудийном производстве и в экономике на рубеже неолита и энеолита.

Следующий период развития в истории региона представляет интерес тем, что открыты и введены в научный оборот памятники эпохи ранней бронзы. Исторической особенностью наследия этой эпохи является наличие в составе населения представителей различных культур. И, по мнению автора, «<..> здесь 
они представлены памятниками ямного типа, елунинской и иных культур, представители которых населяли регион в период ранней бронзы до начала андроновской эпохи средней бронзы в XVIII в. до н.э.» [с. 86]. Результаты аналитического осмысления комплекса данных из поселений, погребальных памятников, в том числе орудий производства, антропологического материала, образцов первобытного искусства, украшений и мн. др. позволило ученому прийти к выводам о притоке в Прииртышье населения с западных регионов на рубеже IV-III тыс. до н.э. [с. 87]. По наблюдениям автора эпоха ранней бронзы характеризуется климатическими изменениями и наступлением в XXV-XXIII вв. до н.э. максимально засушливого периода. Такому выводу не противоречит и датировка, полученная в результате анализа радиоуглеродным методом углей из могильника Шидерты 10 [с. 89].

Согласно выводам автора, наличие различных памятников на описываемой территории связано с активным развитием производства. Население региона находилось в тесном контакте с носителями турбинскосейминской культурной традиции. «Двигаясь из глубин Центральной Азии на северо-запад, через Алтай и его рудные месторождения в верховьях Иртыша, Оби и Енисея, они спустились в среднее течение этих рек, где ими были созданы крупные металлургические центры» [с. 90].

Классический период эпохи бронзы, представленный поселениями, погребальными памятниками, наскальным искусством так называемой андроновской эпохи, в Прииртышье представлен в работах многих исследователей и имеет свои характерные узнаваемые признаки. В историогра- фическом обзоре изученных ранее памятников приведены характерные черты наследия и отмечено что, несмотря на значительную представительность, среди открытых учеными 100 памятников исследовано всего 10 памятников. «Материалы всех этих памятников отражают развитие хозяйства и материальной культуры древних скотоводов и земледельцев, которые занимались также горнорудным производством и металлургией» [c. 103]. Они отражают процессы, происходившие в период сложения протокочевой культуры и получившие дальнейшее развитие в культуре скифо-сакских племен.

Опираясь на ранее проведенные исследования, ученый также полагает, что «<..> развитый центр тасмолинской культуры, локализовался вокруг Баянаульского горно-лесного массива, долинам рек Оленты, Шидерты на левобережье Иртыша» [с. 106]. Характеристика культуры раннего железного века в монографии основана на результатах исследований М.К. Кадырбаева и выводах о характерных особенностях тасмолинской культуры, представленной преимущественно курганами с каменными грядами и каменноземляными насыпями и анализу погребального инвентаря.

Вкладом Павлодарской археологической экспедиции (ПАЭ) в изучение культурного наследия эпохи является то, что: «Кроме погребальных сооружений, за последние 20 лет было открыто много поселений этого периода, в том числе тасмолинских» [c. 111]. Автор указывает на памятники, расположенные в урочище Каражира на южном берегу оз. Кудайколь и у ст. Шидерты. «На поселениях исследованы остатки каменных жилищ прямоугольной формы с очагом, най- 
дено большое количество керамики, бронзовых, костяных и каменных предметов, прежде всего, землеройных орудий - мотыг, молотов, абразивов, литейных форм» [c. 111].

Следующий этап исторического развития, именуемый гунносарматским периодом, в наследии Павлодарского Прииртышья представлен преимущественно артефактами, которые были обнаружены вне культурных слоев. В книге приводятся прдеметы вооружения сарматского облика и другие находки. Вместе с тем ПАЭ под руководством В.К. Мерца были исследованы погребения этого времени (к. 1 мог. Ащиколь в г. Екибастузе; к. 2 у стоянки Шидерты 3, в курганной группе Шидерты 17, на пос. Шидертинское 2, у с. Комарицино, на оз. Кудайколь). «Всего на территории области известно около десятка таких находок. Появление образцов сарматского оружия в Прииртышье связано, вероятно, с миграцией или экспансией какой-то части раннесарматского населения на восток, в предгорья Алтая. Случайность обнаружения этих предметов может объясняться потерей оружия во время частых военных столкновений» [с. 116]. По мнению автора, «<..> они связаны с культурой гунно-сарматских племен, переживавших в III-I вв. до н.э. бурный этап своего развития, связанный с внутриэтническими и политическими процессами, происходившими в это время в казахстанской степи» [c. 117]. Так, материалы из с. Павлодарского и кургана 2 у стоянки Шидерты 3 конца I тыс. до н.э. - начала I тыс. н.э., вероятно, свидетельствуют о разносторонних связях кочевников Павлодарского Прииртышья и Южного Приаралья.
В главе, посвященной развитию тюркского периода и изложенной на двух страницах [с. 122-123], описывается стандартная для казахстанской историографии ситуация о выходе на историческую арену Тюркского, Кимакского каганатов. Характерные черты культур населения эпохи становления государственности отражены в соответствии с общей канвой отсутствия теоретического осмысления наследия тюркского периода. Автор верно отметил, что, несмотря на информацию о локализации Кимакского каганата на Иртыше, следов города не обнаружено. Прекрасные знания топографических условий позволили ученому выявить лишь одно поселение Шауке 1, позволившее обнаружить ряд артефактов кимакского времени [с. 123]. Период развитого средневековья, характеризующийся культурным наследием кыпчаков, изложенный на с. 125, иллюстрирован несколькими фотографиями артефактов. Ученый со ссылкой на работы исследователей перечисляет выявленные памятники кыпчаков X-XIII вв. (Ждановский, Леонтьевский, Качирский могильники, у с. Кенжеколь; в к. 2 мог. Тасмола IV (XIV в.), погр. в к. 2 мог. Шидерты 17) и погребение монгольского времени (к. 1 близ стоянки Шидерты 3) (рубеж XIIIXIV вв.) [с. 122-123].

Согласно мнению ученого, «<..> памятники позднего средневековья на территории Павлодарского Прииртышья еще слабо изучены, но в последние два десятилетия был получен новый археологический материал, относящийся к этому времени. Oсобое место среди них занимают памятники, связанные с культурой «Золотой Орды». Они представлены остатками культово-мемориальных сооружений чингизидской знати и 
городищ этого времени» [c. 131]. Среди них - Калабалгасунская (Калабасунская) башня, обнаруженная в 2001 г. археологической экспедицией Павлодарского госуниверситета. Автор также называет памятник позднего средневековья поселение Вторы 3 , исследованного в 2000 г. в Железинском районе. Материалы верхних слоев представлены керамикой с характерным типом орнаментации, аналогии которым известны в позднесредневековых материалах Вознесенского городища и могильника Малый Чуланкуль-1 (XIV-XVII вв.). По мнению В.К. Мерца, «эти находки свидетельствуют о неоднородной этнической структуре населения в данном регионе Северо-Восточного Казахстана, связанной с формированием тюркских народов Юга Западной Сибири, входивших в состав “Золотой орды”» [с. 134]. Однако закат «Золотой орды», приведший к упадку развивавшиеся в северной степи центры и формированию новых культурно-политических и социально-экономических отношений, а впоследствии - к формированию Казахского ханства, не нашли отражения в памятниках материальной культуры. «Об экономических связях местного населения свидетельствуют находки монет различных государств, импортной керамики, появление родовых тамг на отдельных камнях и надгробных памятниках. В этот период формируется собственно казахская культура, представленная материалами этнографического характера» [c. 134].

В целом монография В.К. Мерца в части изложения материалов, содержащих разделы, отражающие ранние этапы истории населения Павло- дарского Прииртышья, многие годы посвятившего поиску и изучению памятников каменного века и эпохи бронзы, свидетельствует о фундаментальном подходе и обширных знаниях ученого. Широта познания, применение комплексных методов, сравнительный анализ артефактов, используемый в процессе исторической реконструкции развития исторических периодов в эпохи технологических производств каменной индустрии, позволили распознать общее и культурные особенности, происходившие на территории региона. Следовательно, периоды развития индустрии каменного века изложены в книге с особой тщательностью и скрупулезностью и заслуживают особого доверия.

Содержание глав книги, связанных с последующим кратким изложением исторической ситуации, в которой данные о периоде развития населения в раннем железном веке, гунно-сарматском периоде на территории Павлодарского Прииртышья соответствуют общей ситуации в казахстанской археологической историографии. Тюркский и другие периоды средневековой эпохи, изложенные очень кратко, порой на одной или двух страницах, заставляют выразить пожелание дальнейшего последовательного исследования и критического осмысления уже накопленных в историографии источников. Необходимо отметить, что, несмотря на определенные сложности, связанные с поиском, изучением многослойных памятников каменного века, ученому удавалось увидеть климатические и другие изменения, происходившие на территории Павлодарского Прииртышья на протяжении многих десятков 
тысяч лет (к примеру 1,5 млн. лет для памятников палеолита). Однако, периоды, связанные с эпохами развития и формирования государств, казахской народности, непосредственно связанные с тюркским этногенезом в материальной культуре, по сведениям автора представлены слабо. Излагая концепцию достоверного последовательного развития истории населения, ученый вынужден излагать свое профессиональное видение, иногда опираясь на скудные данные из разрозненных источников.
Учитывая научно-популярный характер издания, надо отметить, что замечания, которые приведены рецензентом, должны быть адресованы не только автору издания, а в целом представителям казахстанской археологической науки, для которой характерны черты половинчатости и отсутствие изысканий в области вопросов теории развития культурного наследия.

\section{Сведения об авторе:}

Досымбаева Айман Медеубаевна - доктор исторических наук, профессор кафедры евразийских исследований, Евразийский национальный университет им. Л.Н. Гумилева (г. Нур-Султан, Казахстан); aiman_dos@inbox.ru

\section{В.К. Мерцтің "Павлодар Ертісінің материалдық мәдениетінің қысқаша тарихи дамуы" атты монографиясына сын-пікір.} Павлодар: С. Торайғыров атындағы Павлодар мемлекеттік университеті, 2019. 142 б.

\section{А.М. Досымбаева}

Монография өңір аумағында орналасқан зерттелінген және кітап мазмұнда ұсынылған ескерткіштердің хронологиялық кезеңділігіне сәйкес келетін 11 тараудан, әдебиеттер тізімінен тұрады. Ғылыми еңбекте 30 жылдық кезендегі, сондайақ бұрын республикалық және шетелдік басылымдарда жарияланған 200-ден астам мақалалардағы ғылыми ізденістердің қорытындысы берілген. Археологиялық ескерткіштерді кешенді зерттеудің негізгі нәтижелері монография авторының, тәжірибелі және кәсіби ғалым Виктор Карлович Мерцтің, көп жылдар бойы Павлодар өңірінің аумағындағы ізденістері барысындағы ашқан жаңалықтары мен зерттеулеріне негізделеді.

Басылым авторының ғылыми танымының кеңдігі ескерткіштердің тұтас тобын зерттеуге ерекше көзқарасты қалыптастыра алғандығы басылым мәтінінде, графикалық, фотографиялық және картографиялық суреттердің егжей-тегжейлі орындалуынан ерекше байқалады. Белгілі бір ескерткіштердің жатуының ландшафтық ерекшеліктерін тану және олардың құжаттық фотосуреттерімен бірге, олардың сипаттамасын беруі көпшілік оқырман қауымға белгілі бір дәуірдегі халықтың мәдени даму ерекшеліктерін таныстыру және түсінуге мол мүмкіндік береді.

Түйін сөздер: археология, хронология, мұра, тас дәуірі, артефакт

\section{Review to the book of V.K. Merts}

"Brief history of development of material culture in the Pavlodar Irtysh Region". Pavlodar: S. Toraigyrov Pavlodar State University, 2019. 142 p.

\section{A.M. Dossymbayeva}

The monograph consists of Introduction, 11 chapters corresponding to the chronological periodization of the studied and presented in the content sites located in the region, the list of references. The scientific work sums up the results of scientific research 
for the 30-year period and previously published in more than 200 articles in national and foreign publications. The main results of the comprehensive study of the archaeological sites are based on the discoveries and studies of Victor K. Merts, the monograph's author, experienced and professional scientist, who dealt many years to the research in the Pavlodar Irtysh Region.

The breadth of scientific knowledge of the publication's author allowed to develop a special approach to the study of entire groups of sites is reflected in the text of the publication, meticulously executed graphic, photographic and cartographic illustrations. Of great interest is the ability to recognize the landscape features of the occurrence of certain sites and their documentary photo support, which together with their description provides a wide range of readers the opportunity to be acquainted and understand the peculiarities of cultural development of population in a particular era.

Keywords: archaeology, chronology, heritage, epoch, the Stone Age, artifact

\section{About the Author:}

Dossymbaeva Aiman M. Doctor of historical sciences, professor, department of Eurasian investigations, L.N. Gumilyov Eurasian National University, Nur-Sultan, Kazakhstan; aiman_dos@inbox.ru 